\title{
Hydrological simulation of flood transformations in the upper Danube River: Case study of large flood events
}

\author{
Veronika Bačová Mitková ${ }^{*}$, Pavla Pekárová ${ }^{1}$, Pavol Miklánek ${ }^{1}$, Ján Pekár ${ }^{2}$ \\ ${ }^{1}$ Institute of Hydrology, Slovak Academy of Sciences, Dúbravská cesta 9, 84104 Bratislava, Slovakia. \\ ${ }^{2}$ Comenius University, Faculty of Mathematics, Physics and Informatics, Mlynská dolina F1, 84248 Bratislava, Slovakia. \\ ${ }^{*}$ Corresponding author. Tel.: +421/2 32293502. E-mail: mitkova@uh.savba.sk
}

\begin{abstract}
The problem of understand natural processes as factors that restrict, limit or even jeopardize the interests of human society is currently of great concern. The natural transformation of flood waves is increasingly affected and disturbed by artificial interventions in river basins. The Danube River basin is an area of high economic and water management importance. Channel training can result in changes in the transformation of flood waves and different hydrographic shapes of flood waves compared with the past. The estimation and evolution of the transformation of historical flood waves under recent river conditions is only possible by model simulations. For this purpose a nonlinear reservoir cascade model was constructed. The NLN-Danube nonlinear reservoir river model was used to simulate the transformation of flood waves in four sections of the Danube River from Kienstock (Austria) to Štúrovo (Slovakia) under relatively recent river reach conditions. The model was individually calibrated for two extreme events in August 2002 and June 2013. Some floods that occurred on the Danube during the period of 1991-2002 were used for the validation of the model. The model was used to identify changes in the transformational properties of the Danube channel in the selected river reach for some historical summer floods (1899, 19541965 and 1975). Finally, a simulation of flood wave propagation of the most destructive Danube flood of the last millennium (August 1501) is discussed.
\end{abstract}

Keywords: Danube River; June 2013 flood; Hydrological nonlinear river routing model; Catastrophic flood scenario.

\section{INTRODUCTION}

Routing a flood through the concentrated storage of a reservoir is a hydrological procedure for estimating the changes in magnitude, speed and shape of the flood hydrograph at one or more downstream points along a river as the flood wave progresses downstream. Conceptual hydrological models often only reflect the typical and characteristic behavioural prototypes, while a physical system works with actual data and responds to actual inputs. These models consist of a combination of physically-based components (transformation components linear or nonlinear reservoirs), which simulate the behaviour of the prototypes. A mathematical description of a flood wave transformation by hydrological routing methods was derived and discussed in much research work, e.g., Goodrich (1931) reservoir routing; McCarthy (1938) - the Muskingum routing model; Linsley et al. (1949) - Lag and K routing; Kalinin and Milyukov (1957) - the Kalinin-Milyukov model and Nash (1957, 1960) - the Nash model.

The development of conceptual nonlinear reservoir cascade models was one of several approaches to incorporate nonlinearity into hydrological routing models (see, e.g., Corbus, 2002; Laurenson, 1964; Malone and Cordery, 1989; Svoboda, 1969, 1970). A theoretical justification of changes in wave speeds depending on the size of the discharge was investigated by Wong and Laurenson (1984), Price (1973) and Tang et al. (2001). The number of practical applications of such mathematical models and methods has grown continuously, especially in such important areas as flood forecasts in real time, flood protection, the planning and design of hydraulic structures, the simulation of flood wave scenarios, and simulations of runoff under changed climate or land use conditions. Some recent advances in the Muskingum-based discharge routing methods can also be found in Todini (2007), Price (2009), Sahoo (2013), and Perumal and Price (2013). Kim and Georgakakos (2014) dealt with hydrologic routing using a nonlinear cascaded reservoir model where the functions were only required to be nondecreasing. They modelled river reach as conceptual reservoir cascades, with discharge-storage and loss/gain functions identified from the data. Tarpanelli et al. (2013) estimated river discharges using altimetry data and simplified flood routing modelling. The procedure was based on the application of the Rating Curve Model, a simple method allowing for the estimation of the flow conditions in a river section using only water levels recorded at that site and the discharges observed at another upstream section. Szilagyi et al. (2008) applied a simple flow routing technique, i.e., the discrete linear cascade model (DLCM), to identify historical changes in the stage-discharge relationship along the Nebraska City-Rulo section of the Missouri River.

Danáčová et al. (2015) used the discrete state-space representation of the Kalinin-Miljukov model as a multi-linear flood routing model for studying the relationship between the traveltime of flood peaks and peak discharges on a reach of the Poprad River. The first model defines a flow in a channel and the second one a flow during an inundation.

For the Danube River, several flood wave transformation models were developed and tested in the past. Svoboda et al. (2000) used the NONLIN nonlinear cascade model for transformation of the flood waves in the Bratislava-Nagymaros river reach. In Pekárová et al. (2004) and Mitková et al. (2004), two different hydrological flood routing models, i.e., the NLNDanube cascade of nonlinear reservoirs and the KLN multilinear version of the cascade of linear reservoirs (Szolgay, 2003), were set up for the Stein Krems/KienstockDevín/Bratislava reach. The validation of the results obtained showed that both models represented the present hydraulic conditions in the given river reach adequately.

However, the river regime conditions of the Danube River are always changing. These changes result from either natural 
processes (erosion, sedimentation, vegetation cover) or anthropogenic activities (modification of a riverbank, construction of hydro-power stations). Three waterworks have been put into operation since 1970 in the Kienstock-Štúrovo river reach: Altenwörth (1973-1976), Greifenstein (1982-1985) and Freudenau (1992-1997) and one since 1993: the Gabčíkovo power plant (Hrušov reservoir - $196 \mathrm{mil}^{3} \mathrm{~m}^{3}$ ). This may have had a significant impact upon the flood wave transformation changes (Bardossy and Molnar, 2004). Čížová (1992) and Opatovská (2002) analysed travel time and water level relations on the Danube at Bratislava. Their results show that the travel times of the 1991-2002 medium floods are shorter by about $41 \%$ compared to $1923-1966$ in the Linz-Bratislava river reach. The travel times of the biggest floods (the 1954 and 2002 floods) did not change significantly.

As was mentioned above, the estimation and evolution of the transformation of historical flood waves under recent river conditions is possible through hydrological model simulations. For this purpose a hydrological routing method was used to construct the NLN-Danube nonlinear reservoir cascade model in 2004. The recent June 2013 flood in the Upper Danube reach was the largest in the last 114 years, so it allows for a more robust testing and validation of the model than was possible before.

The main aim of this study is to evaluate the accuracy of the NLN-Danube model for a simulation of the June 2013 flood event and compare the model's efficiency and the parameters of the model calibrated with the August 2002 and June 2013 floods. Significant floods that occurred on the Danube during the period of 1991-2010 have been selected and used for the validation of the NLN-Danube model. Then, the simulations of some large historical floods $(1899,1954,1965$, and 1975) are evaluated. Finally, a simulation of a catastrophic flood scenario for recent river conditions (based on the historical Danube flood from the year 1501) is presented. The 1501 flood is considered to be the greatest flood that occurred in the Upper Danube basin during the last 600 years.

DATA

\section{Study area}

The Danube River is the second largest river in Europe after the Volga. The basin covers an area of $817,000 \mathrm{~km}^{2}$. The length of the river is $2,872 \mathrm{~km}$. The river originates from the Black Forest in Germany at the confluence of the Brigach and the Breg streams. It discharges into the Black Sea via the Danube delta, which lies in Romania and Ukraine (Figure 1).

The Upper Danube region extends from its source tributaries to the Devín Gate at its confluence with the Morava. After the confluence of the Briga and Breg streams, the river is called the Danube (Donau in German). Downstream from this point the river follows a fault gap through the German Alps and its wellshaped valley. Its major tributaries come from the south, including rivers from Alpine sub-basins, and substantially augment the discharge in the Danube. For example, the river Inn has a larger mean annual discharge than the Danube itself at its confluence. Originally, these mountain tributaries transported large amounts of sediments, but the sediment load is now greatly reduced because of the construction of hydraulic works. Major tributaries from the north are the rivers Naab, Kamp and Morava/March. The Morava is the most important one and drains the Czech part of the Danube river basin and smaller areas of Slovakia and Austria. The Slovak part of the Upper Danube region (Figure 2) is situated in the south-western part of the country. A length of around $7.5 \mathrm{~km}$ of the Danube River forms a natural border with Austria; $22.5 \mathrm{~km}$ is in Slovakia, and the remaining $142 \mathrm{~km}$ forms the state border with Hungary. Between Vienna and the Danube lowlands, the Danube flows in a concentrated channel with a relatively high bed slope. After leaving the Small Carpathians, it keeps the slope and flows over its alluvial cone through a complicated network of branches and meanders downstream to the town of Medved'ov (Slovakia).

\section{Historical floods on the Danube River}

The occurrence of large floods on the Danube River is described in detail in many publications (e.g. Horváthová, 2003; Brázdil and Kundzewicz, 2006; Kiss, 2011; Kjeldsen et al., 2014; Melo et al., 2014; and Pekárová, et al., 2014). Some floods in the Upper (from their source to Bratislava), Central and Lower Danube (from Orsova to the Black Sea) stream do not occur usually occur simultaneously. The courses of some extreme floods are presented in Figure 3 a-c. For example, some floods (1897, 1899, 1954 and August 2002) were characterized as extreme especially for the Upper Danube. On the other hand, the floods that occurred in 1897, 1940, 1942, 1970,

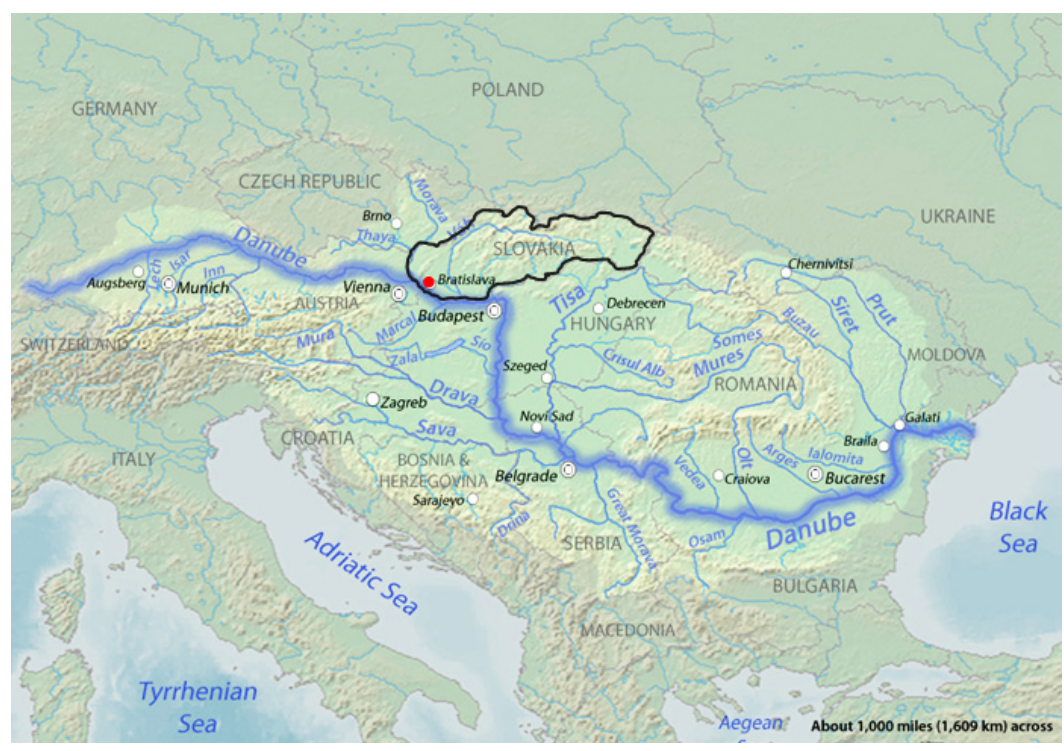

Fig. 1. Map of the Danube River basin. 


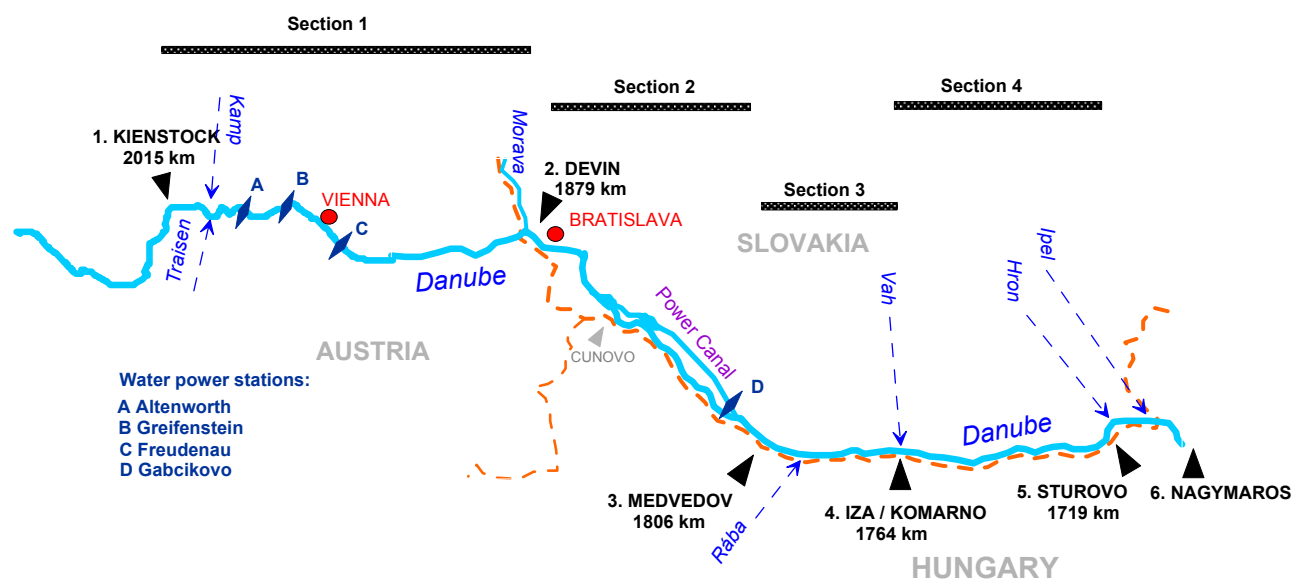

Fig. 2. Scheme of the Danube River, selected sections and water gauging stations.

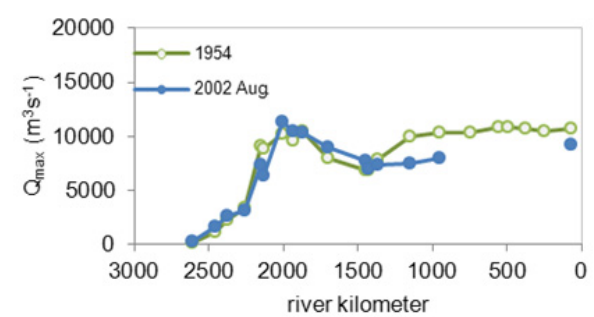

a

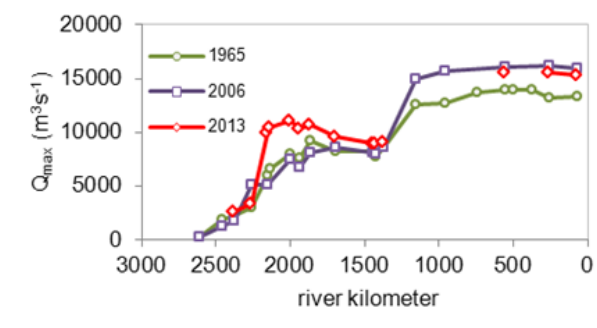

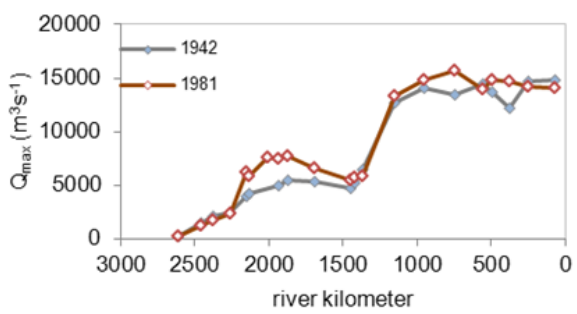

b

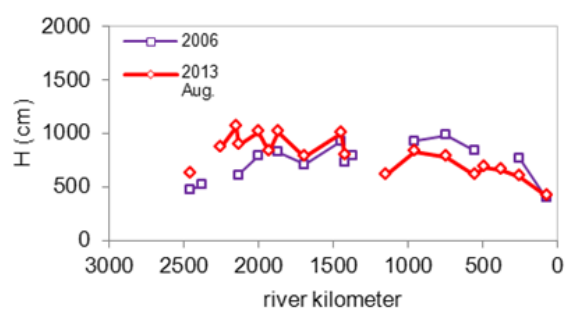

d

Fig. 3. Course of some extreme floods along the Danube River, a) Upper Danube River floods in 1954, Aug 2002., b) Lower Danube River floods in 1942, 1981, c) floods in 1965, 2006 and 2013 - along the entire length of the Danube River and d) maximum water levels during the 2006 and 2013 floods.
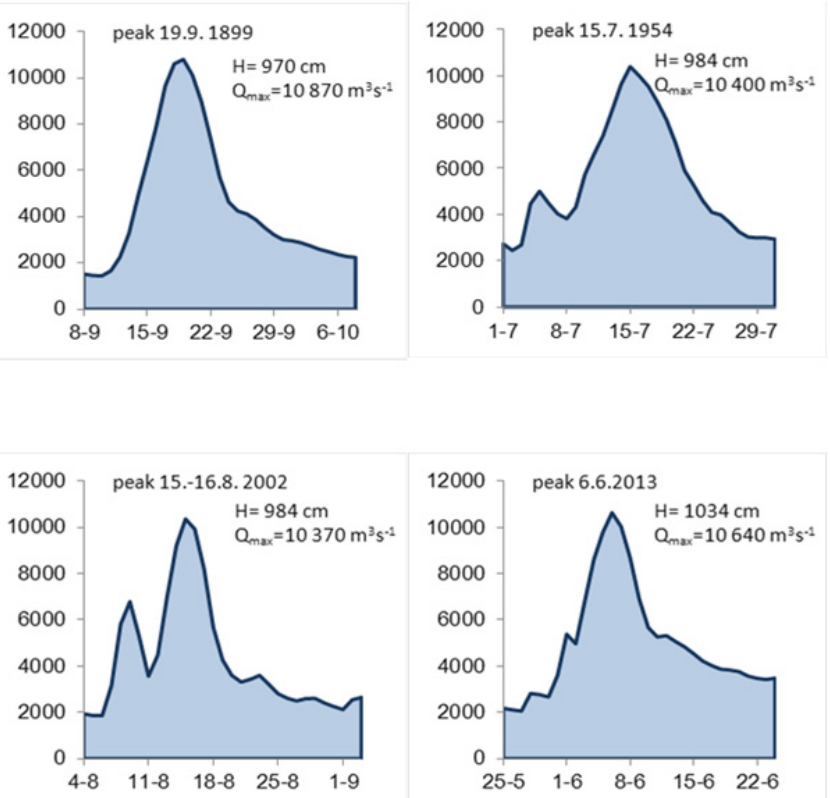

b

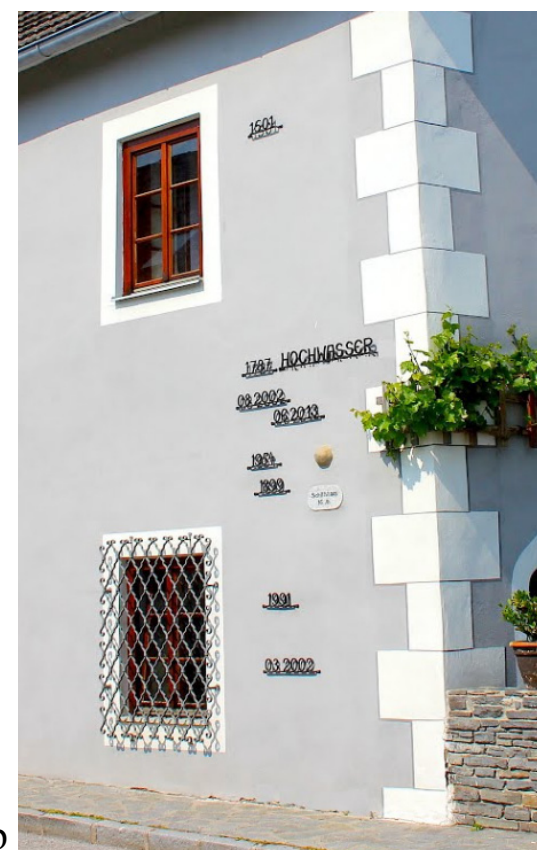

Fig. 4. a) Hydrographs of Danube floods with discharges of over $10,000 \mathrm{~m}^{3} \mathrm{~s}^{-1}$ at the Bratislava gauge since 1899 , and b) The Danube flood marks, Emmersdorf an der Donau. (Photo Alexander Szep, 2014, http://www.panoramio.com/photo/106599261) 
1980 and 1981 were characterized as extreme especially for the Lower Danube. The floods which occurred in 1899, 1965, 2006, and 2013 can be characterized as extreme for the entire length of the Danube River.

According to Kresser (1957), the largest peak discharge on the Upper Danube at Vienna was estimated to have a value of $14,000 \mathrm{~m}^{3} \mathrm{~s}^{-1}$ (the year 1501). During the period of 1900-2013, the largest peak discharge was measured on the Upper Danube at Kienstock $\left(11,450 \mathrm{~m}^{3} \mathrm{~s}^{-1}\right.$ in 2013) and on the Lower Danube at Ceatal Izmail $\left(15,900 \mathrm{~m}^{3} \mathrm{~s}^{-1}\right.$ in 2006). Figure $3 \mathrm{~d}$ illustrates the maximum water levels along the Danube River reached during the floods in 2006 and 2013 (Mikhailova et al., 2012). Blöschl et al. (2013) described the June 2013 flood in the Upper Danube basin, including the local atmospheric and meteorological conditions and the runoff generation, and compared it to the floods in 2002, 1954 and 1899. Hydrographs of four floods with peak discharges over $10,000 \mathrm{~m}^{3} \mathrm{~s}^{-1}$ at the Bratislava water gauge station are illustrated in Figure 4a.

\section{METHODOLOGY}

\section{Nonlinear routing NLN-Danube model}

The NLN-Danube model which is presented in this paper, simulates flood wave transformations in the four river sections from Štúrovo to Kienstock. The Kienstock upstream water gauging station was chosen for its sufficient distance from Bratislava with respect to the flood control arrangements, and because it has already takes the significant Alpine tributaries into the Danube River. For example, the travel time of the peaks of the September 1899 flood $\left(10,870 \mathrm{~m}^{3} \mathrm{~s}^{-1}\right.$ at Bratislava) and the August 2002 flood $\left(10,390 \mathrm{~m}^{3} \mathrm{~s}^{-1}\right.$ at Bratislava) was estimated to have values of 45 and 47 hours, respectively, from Kienstock to Bratislava (Mitková and Pekárová, 2003).

The NLN-Danube model was derived from the NONLIN (Pekárová et al., 2001; Svoboda and Hajtášová, 1996; Svoboda et al., 2000) nonlinear model. The NLN-Danube model of each section of the simulated system is based upon the concept of a series of equal nonlinear reservoirs, thus belonging to the category of nonlinear conceptual hydrological models. The model's input $\left(P-\right.$ discharge $\left.\left[\mathrm{m}^{3} \mathrm{~s}^{-1}\right]\right)$ represents the input into the first reservoir of the cascade; its output is the input into the second one in the series, etc., and the output from the last reservoir is the output $\left(Q-\right.$ discharge $\left.\left[\mathrm{m}^{3} \mathrm{~s}^{-1}\right]\right)$ from the model of the section. The movement of the wave through the reservoir is defined by flow $(Q)$ and by the volume of the reservoir $(V)$ as:

$$
Q=B \cdot V^{E X}
$$

where $Q$ is the reservoir output $\left[\mathrm{m}^{3} \mathrm{~s}^{-1}\right] ; V\left[\mathrm{~m}^{3}\right]$ is the volume of the reservoir's storage; the exponent $E X$ is the nonlinearity parameter [-]; and $B[-]$ is the proportionality parameter.

The flood wave's propagation is modelled in equidistant discrete time steps of $0,1,2, \ldots, m$. The difference between two steps is given by the parameter $\Delta T[\mathrm{hr}]$. In time steps $i$ and $i+1$, for known input $P_{i+l}$ and output $Q_{i}$, the unknown output $Q_{i+1}$ is determined from the continuity equation within the time interval $i+1$ of the length $\Delta T$ as:

$$
\left(P_{i+1}-Q_{i+1}\right) \cdot \Delta T=V_{i+1}-V_{i},
$$

where $P_{i+1}, Q_{i+1}$ are the average input/output of the interval $i+1$; $V_{i+1}, V_{i}$ are the storage at the interval $i+1$ and $i$. From equations (1) and (2) we receive:

$$
\left(P_{i+1}-Q_{i+1}\right) \cdot \Delta T=\frac{Q_{i+1}^{1 / E X}-Q_{i}^{1 / E X}}{B^{1 / E X}} .
$$

Equation (3) defines the nonlinear function $f$ of one unknown, $Q_{i+1}$,

$f\left(Q_{i+1}\right)=\left(P_{i+1}-Q_{i+1}\right) \cdot \Delta T-\frac{Q_{i+1}^{1 / E X}-Q_{i}^{1 / E X}}{B^{1 / E X}}$,

this is solved by the linearization (Newton) method

$Q_{i+1}^{(k+1)}=Q_{i+1}^{(k)}-\frac{f\left(Q_{i+1}^{(k)}\right)}{f^{\prime}\left(Q_{i+1}^{(k)}\right)}$.

It gives in our case the iteration formula:

$$
Q_{i+1}^{(k+1)}=Q_{i+1}^{(k)}+\frac{\left(P_{i+1}-Q_{i+1}^{(k)}\right) \cdot \Delta T-\left[\left(Q_{i+1}^{(k)}\right)^{1 / E X}-\left(Q_{i}\right)^{1 / E X}\right] \cdot B^{-1 / E X}}{\Delta T+\left(Q_{i+1}^{(k)}\right)^{(1-E X) / E X} \cdot B^{-1 / E X} \cdot E X^{-1}} .
$$

The parameters of the transformation curve shape are expressed by the proportionality of parameter $B$,

$$
B=\left(\frac{N . \Delta T}{B K}\right)^{E X}
$$

where $N$ is the amount of storage in the section of the model, $B K$ is the time constant of an equivalent linear system [hr], and $Q C$ corresponds to the maximum capacity of the main river channel (the discharge, when water enters into the inundation) $\left[\mathrm{m}^{3} \mathrm{~s}^{-1}\right]$. The additional model parameters $N U$ and $N L$ represent external inputs into the section near the upper $(N U)$ or lower $(N L)$ station (if tributaries exist, the value of the parameter is 1 , and the model includes any flow from the tributary).

In order to ascertain the same degree of accuracy of the routing, which is respective of the units used of the discharge and volume (Eq. 3), the input and output in the model are transformed into dimensionless values by:

$$
p=\frac{P}{Q C} \text { and } q=\frac{Q}{Q C}
$$

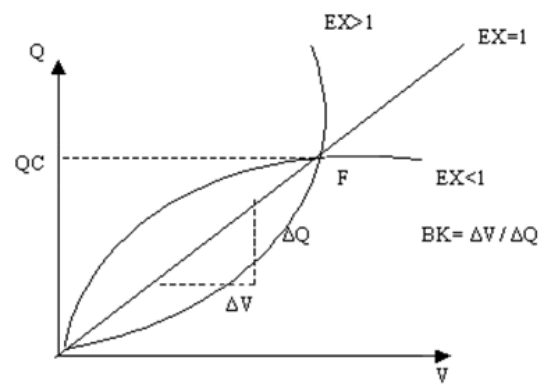

Fig. 5. Transformation functions - shape of the routing curve in the NLN-Danube model. Parameters $E X, B K$ and $Q C$ define the position of the point $F$, and, consequently the attenuation effect below and above this point. 
Hydrological simulation of flood transformations in the upper Danube River: Case study of large flood events

Table 1. Parameters of the NLN-Danube model and their characterization.

\begin{tabular}{ll}
\hline $\begin{array}{l}\text { Parameters } \\
\text { of the model }\end{array}$ & Description \\
\hline$B K$ & Time constant of an equivalent linear system \\
\hline$Q C$ & Maximum capacity of the main river channel \\
\hline$E X$ & Nonlinearity parameter \\
\hline$N$ & Amount of storage in one section of the model \\
\hline$N U$ & $\begin{array}{l}\text { Existence of external input to the upper end of the section (if Yes enter } 1, \text { if No enter } 0) . \text { If NU }=1 \\
\text { model includes the flow from tributaries to simulation }\end{array}$ \\
\hline$N L$ & $\begin{array}{l}\text { Existence of external input to the lower end of the section (if Yes enter } 1, \text { if No enter } 0) . \text { If NL }=1 \\
\text { model includes the flow from tributaries to simulation }\end{array}$ \\
\hline
\end{tabular}

The physical meaning of the parameters defining the shape of the routing curve is demonstrated in Figure 5, and the characterization of the model parameters is listed in Table 1. The procedure for the calibration and validation of the model is performed by the trial and error method. The parameters of $B K$, $N U$ and $N L$ are first defined. Next, the parameters of $N, E X$ and $Q C$ are defined. The flow data from the Danube water gauging stations as well as the tributaries are used as input data.

\section{NLN-Danube model evaluations}

For an evaluation of the quality of the model simulations, the following statistical indicators of the goodness of fit of the estimation were used: the Pearson coefficient of correlation $R[-]$, the mean error $M E\left[\mathrm{~m}^{3} \mathrm{~s}^{-1}\right]$, the mean absolute percentage error MAPE [\%] and the maximum absolute error $M A X\left[\mathrm{~m}^{3} \mathrm{~s}^{-1}\right]$.

Pearson coefficient of correlation:

$$
R=\frac{\sum_{t=1}^{N}\left(\left(Q_{m}(t)-\bar{Q}_{m}\right)\left(Q_{f}(t)-\bar{Q}_{f}\right)\right)}{\sqrt{\sum_{t=1}^{N}\left(Q_{m}(t)-\bar{Q}_{m}\right)^{2} \sum_{t=1}^{N}\left(Q_{f}(t)-\bar{Q}_{f}\right)^{2}}} .
$$

Mean error

$$
M E=\frac{1}{N} \sum_{t=1}^{N}\left(Q_{m}(t)-Q_{f}(t)\right) .
$$

Mean absolute percentage error

$$
M A P E=\frac{1}{N} \sum_{t=1}^{N}\left|\frac{Q_{m}(t)-Q_{f}(t)}{Q_{m}(t)}\right| .
$$

Maximum absolute error

$$
M A X=\max \left|Q_{m}(t)-Q_{f}(t)\right|
$$

where $Q_{m}$ and $Q_{f}$ are measured and simulated discharges, respectively.

\section{RESULTS AND DISCUSSION Simulation of the June 2013 flood by the NLN -Danube model}

The NLN-Danube nonlinear river model, which was calibrated with the August 2002 Danube flood event and validated with some smaller earlier floods, was used for the real-time forecasting of the wave transformation of the June 2013 flood on the Danube River at the Kienstock-Štúrovo reach. The hydrological situation of the June 2013 flood on the Slovak part of the Danube River is described in the publications of the Slovak Hydrometeorological Institute, e.g., Blaškovičová et al. (2013). The hourly discharges measured at the Kienstock gauge were used as the input data for the model. The simulation of the June 2013 flood wave transformation along the Danube reach of Kienstock-Štúrovo is illustrated in Figure 6. For each section of the Danube River reach, the main statistical characteristics of the simulated and measured discharges and the errors of the simulation were calculated and are listed in Table 2. The maximal value of the MAX error of the model between the simulated and measured discharges was reached for Devín/Bratislava (a decreasing limb), and the maximal value of MAPE was reached for Stúrovo. The minimal value of the correlation coefficient $\mathrm{R}$ reached a value of 0.977 (Iža). The model simulated a faster rise in the flood wave up to $5500 \mathrm{~m}^{3} \mathrm{~s}^{-1}$ for the Medved'ov and Iža gauging stations and significantly underestimated the discharges at the Medved'ov station. The simulated maximum discharge reached a lower value by about $651 \mathrm{~m}^{3} \mathrm{~s}^{-1}$ (Table 2).

Therefore, in the next step some model parameters $(N, B K$, $Q C$ and $E X)$ were changed for a better simulation of the June, 2013 flood, especially for the Medved'ov station. Subsequently, the parameters for Iža and Štúrovo were adapted. The values of the new parameters of the June 2013 flood are listed in Table 3. Figure 7 illustrates the simulation of the transformation of the June 2013 flood wave at the Kienstock-Štúrovo reach with new parameters. Figure 7 shows better results for the simulation. The main statistical characteristics of the simulated and measured discharges of the 2013 flood, as well as the errors of the model with new parameters, were calculated and are listed in Table 4. The simulated peak values and simulated volumes achieved better results. The minimal value of the correlation coefficient achieved a value of 0.982 (Medved'ov).

The validation of the model with the 2013 flood parameters was performed for the Danube summer floods in July 1991, July 1997, March 2002, August 2002, and June 2010.

The results of the model's validation for the present river conditions showed overestimated discharges at Medved'ov.

The differences between the simulated and measured peak discharges reached values of over $500 \mathrm{~m}^{3} \mathrm{~s}^{-1}$ for the second flood wave in July 1997, the flood waves in August 2002, and the ones in June 2010. Graphic examples of the model's validation of the 1991, 1997, and 2002 floods with the model parameters of the June 2013 event are presented in Figure $8 \mathrm{a}-\mathrm{c}$.

The validation values of the simulated and measured discharges as well as the Pearson coefficient of the correlation of the simulation are listed in Table 5. The model parameters obtained by calibration with the 2013 flood as well as validation of the model were compared with the results obtained by calibration with the August 2002 flood. 
Table 2. Simulation of the flood in June 2013 by NLN-Danube model (calibrated with August 2002 event).

\begin{tabular}{lcccc}
\hline Attribute & Devín/Bratislava & Medved'ov & Iža & Štúrovo \\
\hline Measured $Q_{\max }\left[\mathrm{m}^{3} \mathrm{~s}^{-1}\right]$ & 10,640 & 10,160 & 9,497 & 9,488 \\
Simulated $Q_{\max }\left[\mathrm{m}^{3} \mathrm{~s}^{-1}\right]$ & 10,610 & 9,509 & 9,453 & 9,351 \\
Measured Volume $\left[10^{6} \mathrm{~m}^{3}\right]$ & 13,605 & 12,902 & 13,848 & 14,055 \\
Simulated Volume $\left[10^{6} \mathrm{~m}^{3}\right]$ & 12,966 & 12,518 & 13,046 & 13,022 \\
$R[-]$ & 0.990 & 0.979 & 0.977 & 0.983 \\
$M E\left[\mathrm{~m}^{3} \mathrm{~s}^{-1}\right]$ & 238.6 & 143 & 299 & 385 \\
$M A X\left[\mathrm{~m}^{3} \mathrm{~s}^{-1}\right]$ & $1,933.8$ & $1,031.7$ & 1,343 & 1,434 \\
$M A P E[\%]$ & 5.9 & 6.6 & 7.8 & 8.0 \\
\hline
\end{tabular}

$M E$ - mean error, $M A X$ - maximum absolute error, $M A P E$ - mean absolute percentage error.

Table 3. Values of the NLN-Danube model parameters for the Kienstock - Štúrovo reach (calibrated with June 2013 event).

\begin{tabular}{lcccc}
\hline Parameter & KI-DE & DE-ME & ME-IZ & IZ-ST \\
\hline$N$ & 3 & 3 & 1 & 1 \\
$N U$ & 1 & 0 & 1 & 0 \\
$N L$ & 0 & 1 & 0 & 0 \\
\hline$B K$ & 8 & 6.9 & 4.5 & 3 \\
$Q C$ & 5,400 & 6,000 & 3,000 & 3,500 \\
$E X$ & 0.43 & 0.42 & 0.4 & 0.7 \\
\hline
\end{tabular}

Table 4. Simulation of the flood in June 2013 by NLN-Danube model (calibrated with June 2013 event).

\begin{tabular}{lcccc}
\hline Attribute & Devín/Bratislava & Medved'ov & Iža & Štúrovo \\
\hline Measured $Q_{\max }\left[\mathrm{m}^{3} \mathrm{~s}^{-1}\right]$ & 10,640 & 10,160 & 9,497 & 9,488 \\
Simulated $Q_{\max }\left[\mathrm{m}^{3} \mathrm{~s}^{-1}\right]$ & 10,610 & 10,100 & 9,416 & 9,392 \\
Measured Volume $\left[10^{6} \mathrm{~m}^{3}\right]$ & 13,605 & 12,902 & 13,848 & 14,055 \\
Simulated Volume $\left[10^{6} \mathrm{~m}^{3}\right]$ & 12,966 & 12,521 & 13,059 & 13,174 \\
$R[-]$ & 0.990 & 0.982 & 0.990 & 0.987 \\
$M E\left[\mathrm{~m}^{3} \mathrm{~s}^{-1}\right]$ & 238.6 & 322.8 & 246 & 329 \\
$M A X\left[\mathrm{~m}^{3} \mathrm{~s}^{-1}\right]$ & $1,933.8$ & $1,516.2$ & 952 & 1,223 \\
$M A P E[\%]$ & 5.9 & 6.1 & 6.2 & 7 \\
\hline
\end{tabular}

$M E$ - mean error, $M A X$ - maximum absolute error, $M A P E$ - mean absolute percentage error.
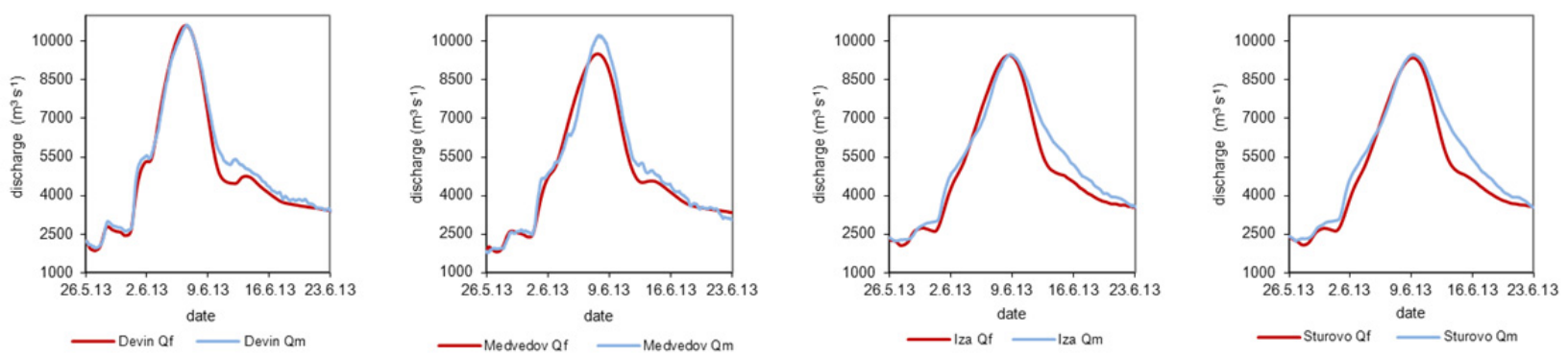

Fig. 6. Transformation of the June 2013 flood wave simulated with NLN-Danube model at the Kienstock-Šturovo reach (calibrated with August 2002 event) $\left(Q_{m}\right.$ - measured discharges, $Q_{f}$ - simulated discharges).
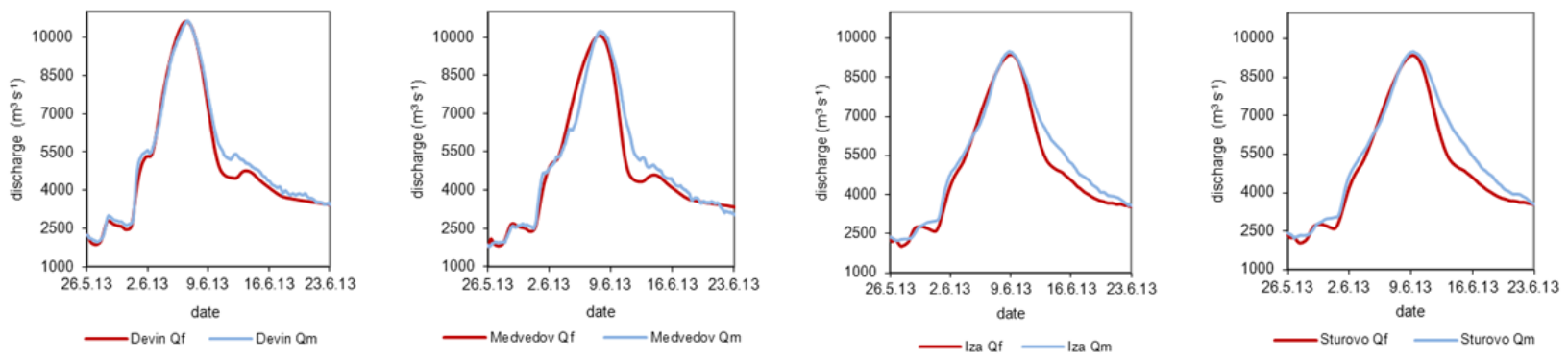

Fig. 7. Transformation of the June 2013 flood wave simulated with NLN-Danube model at the Kienstock-Štúrovo reach (calibrated with June 2013 event) ( $Q_{m}$ - measured discharges, $Q_{f^{-}}$simulated discharges). 
Table 5. Results of the validation of the NLN-Danube model (calibrated with June 2013 event).

\begin{tabular}{|c|c|c|c|c|c|}
\hline Flood & Atribute & Devín/Bratislava & Medved'ov & Iža & Štúrovo \\
\hline & Meas. $Q_{\max }\left[\mathrm{m}^{3} \mathrm{~s}^{-1}\right]$ & 9,430 & 8,444 & 8,026 & 8,070 \\
\hline \multirow[t]{2}{*}{1991} & Sim. $Q_{\max }\left[\mathrm{m}^{3} \mathrm{~s}^{-1}\right]$ & 9,385 & 8,879 & 8,205 & 8,169 \\
\hline & $R[-]$ & 0.996 & 0.964 & 0.987 & 0.956 \\
\hline \multirow[t]{3}{*}{ July $1997 *$} & Meas. $Q_{\max }\left[\mathrm{m}^{3} \mathrm{~s}^{-1}\right]$ & 7,432 & 6,594 & 7,133 & 7,150 \\
\hline & Sim. $Q_{\max }\left[\mathrm{m}^{3} \mathrm{~s}^{-1}\right]$ & 6,964 & 6,631 & 7,236 & 7,202 \\
\hline & $R[-]$ & 0.990 & 0.991 & 0.996 & 0.975 \\
\hline \multirow[t]{3}{*}{ July $1997 * *$} & Meas. $Q_{\max }\left[\mathrm{m}^{3} \mathrm{~s}^{-1}\right]$ & 7,236 & 6,380 & 7,088 & 7,380 \\
\hline & Sim. $Q_{\max }\left[\mathrm{m}^{3} \mathrm{~s}^{-1}\right]$ & 7,365 & 7,014 & 7,200 & 7,176 \\
\hline & $R[-]$ & 0.990 & 0.991 & 0.996 & 0.975 \\
\hline \multirow[t]{3}{*}{ March 2002} & Meas. $Q_{\max }\left[\mathrm{m}^{3} \mathrm{~s}^{-1}\right]$ & 8,628 & 7,913 & 7,720 & 7,600 \\
\hline & Sim. $Q_{\max }\left[\mathrm{m}^{3} \mathrm{~s}^{-1}\right]$ & 8,356 & 7,960 & 7,501 & 7,467 \\
\hline & $R[-]$ & 0.998 & 0.989 & 0.997 & 0.993 \\
\hline \multirow[t]{3}{*}{ August 2002} & Meas. $Q_{\max }\left[\mathrm{m}^{3} \mathrm{~s}^{-1}\right]$ & 10,390 & 9,240 & 8,940 & 9,103 \\
\hline & Sim. $Q_{\max }\left[\mathrm{m}^{3} \mathrm{~s}^{-1}\right]$ & 10,440 & 9,754 & 8,963 & 8,935 \\
\hline & $R[-]$ & 0.996 & 0.983 & 0.994 & 0.989 \\
\hline \multirow[t]{3}{*}{2010} & Meas. $Q_{\max }\left[\mathrm{m}^{3} \mathrm{~s}^{-1}\right]$ & start & 6,938 & 8,147 & 8,162 \\
\hline & Sim. $Q_{\max }\left[\mathrm{m}^{3} \mathrm{~s}^{-1}\right]$ & start & 7,177 & 8,138 & 8,112 \\
\hline & $R[-]$ & start & 0.990 & 0.998 & 0.996 \\
\hline
\end{tabular}

Two flood waves over $6000 \mathrm{~m}^{3} \mathrm{~s}^{-1}$ occurred in July 1997:* first wave, ** second wave.
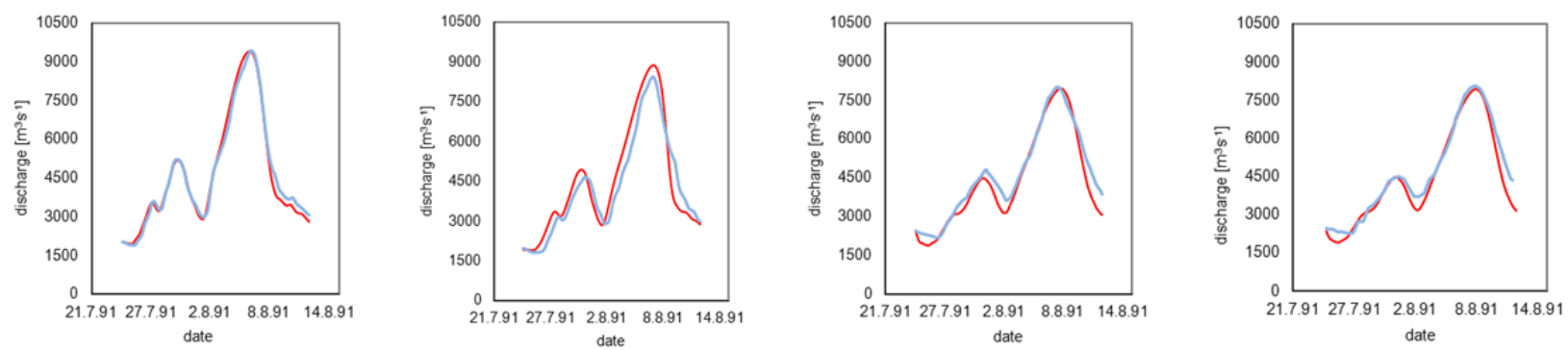

a
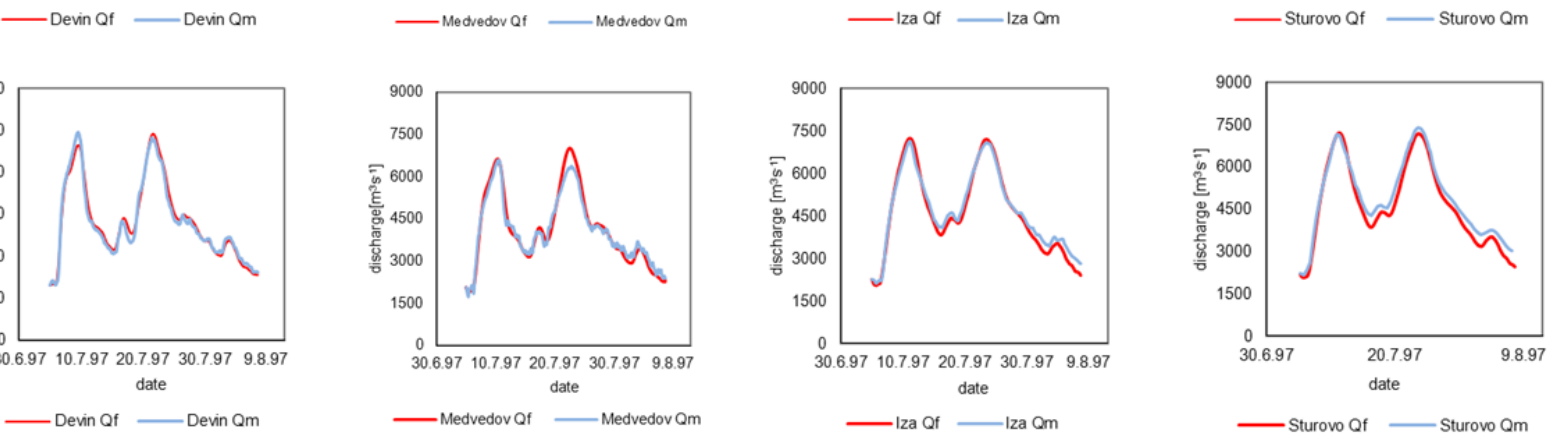

b
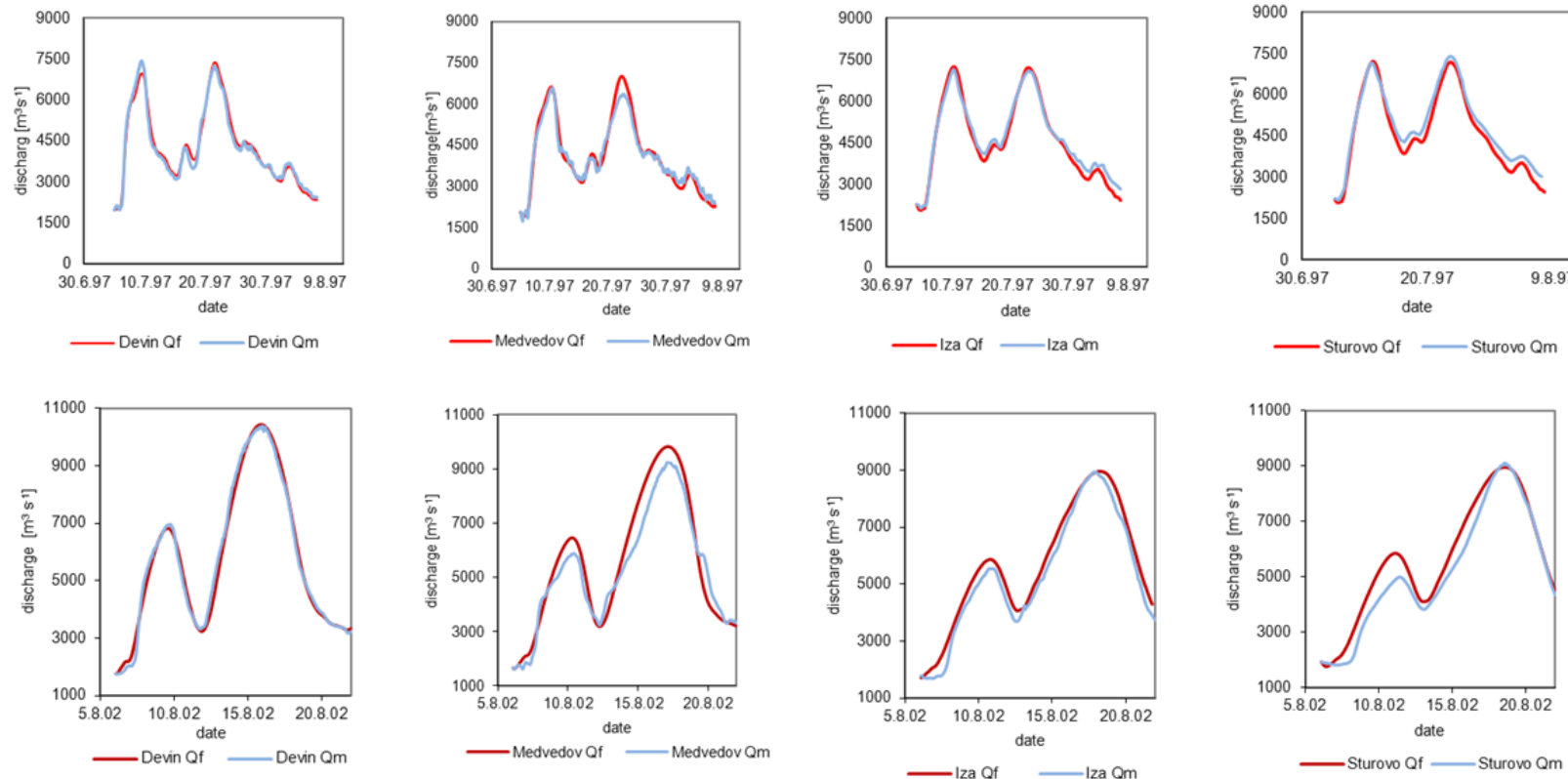

Fig. 8. Validation of the NLN-Danube model at the Kienstock-Štúrovo reach (calibrated with June 2013 event). Validation floods a) 1991 and b) 1997 and c) August 2002 ( $Q_{m}$ - measured discharges, $Q_{f}$ - simulated discharges). 


\section{Comparison of the model validations calibrated with the floods in August 2002 and June 2013}

The values of the calibration parameters of the August 2002 flood for Šúrovo are listed in Table 6. The NLN-Danube nonlinear river model was validated with a set of major summer flood waves on the Danube River from the period of 19912010. The test set consisted of the same flood waves as the validations of the model with the 2013 flood. The results of the validation with the August 2002 flood of the model are listed in Table 7. A graphic example of this model's validation (the 1991, 1997 floods) is presented in Figure 9. The details of the model's calibration and validations for the whole KienstockStúrovo river reach was evaluated and published in Mitková et al. (2005) and Mitková (2005).

The results of the individual calibrations with two extreme events (August 2002 and June 2013) showed the necessity of changing some calibration parameters. The validation of the model, which was calibrated with the flood of June 2013, showed an overestimation of the simulated peak discharges of the earlier floods for the Medved'ov gauging station. These differences could indicate changes in the water regime of the Danube River in the Devín-Medved'ov section and may be caused by anthropogenic impacts. Therefore, calibration of the

Table 6. Values of the NLN-Danube model parameters for Kienstock - Štúrovo reach (calibrated with August 2002 event).

\begin{tabular}{lcccc}
\hline Parameter & KI-DE & DE-ME & ME-IZ & IZ-ST \\
\hline$N$ & 3 & 1 & 1 & 1 \\
$N U$ & 1 & 0 & 1 & 0 \\
$N L$ & 0 & 1 & 0 & 0 \\
\hline$B K$ & 8 & 6 & 7.9 & 6 \\
$Q C$ & 5,400 & 4,300 & 3,100 & 5,300 \\
$E X$ & 0.43 & 0.42 & 0.59 & 0.6 \\
\hline
\end{tabular}

Table 7. Results of the validation of the NLN-Danube model (calibrated with August 2002 event).

\begin{tabular}{lccccc}
\hline Flood & Attribute & Devín/Bratislava & Medved'ov & Iža & Štúrovo \\
\hline \multirow{4}{*}{1991} & Meas. $Q_{\max }\left[\mathrm{m}^{3} \mathrm{~s}^{-1}\right]$ & 9,430 & 8,444 & 8,026 & 8,070 \\
& Sim. $Q_{\max }\left[\mathrm{m}^{3} \mathrm{~s}^{-1}\right]$ & 9,385 & 8,410 & 8,247 & 8,126 \\
July 1997* & $R[-]$ & 0.996 & 0.98 & 0.983 & 0.967 \\
& Meas. $Q_{\max }\left[\mathrm{m}^{3} \mathrm{~s}^{-1}\right]$ & 7,432 & 6,594 & 7,133 & 7,150 \\
\multirow{5}{*}{ July 1997** } & Sim. $Q_{\max }\left[\mathrm{m}^{3} \mathrm{~s}^{-1}\right]$ & 6,964 & 6,633 & 7,236 & 7,200 \\
& $R[-]$ & 0.990 & 0.991 & 0.996 & 0.974 \\
& Meas. $Q_{\max }\left[\mathrm{m}^{3} \mathrm{~s}^{-1}\right]$ & 7,236 & 6,380 & 7,088 & 7,380 \\
March 2002 & Sim. $Q_{\max }\left[\mathrm{m}^{3} \mathrm{~s}^{-1}\right]$ & 7,365 & 6,687 & 7,201 & 7,176 \\
& $R[-]$ & 0.990 & 0.991 & 0996 & 0.974 \\
\multirow{5}{*}{2010} & Meas. $Q_{\max }\left[\mathrm{m}^{3} \mathrm{~s}^{-1}\right]$ & 8,628 & 7,913 & 7,720 & 7,600 \\
& Sim. $Q_{\max }\left[\mathrm{m}^{3} \mathrm{~s}^{-1}\right]$ & 8,356 & 7,555 & 7,491 & 7,376 \\
& $R[-]$ & 0.998 & 0.994 & 0.997 & 0.983 \\
& Meas. $Q_{\max }\left[\mathrm{m}^{3} \mathrm{~s}^{-1}\right]$ & start & 6,938 & 8,147 & 8,162 \\
& Sim. $Q_{\max }\left[\mathrm{m}^{3} \mathrm{~s}^{-1}\right]$ & start & 7,502 & 8,319 & 8,209 \\
\hline
\end{tabular}

Two flood waves over $6000 \mathrm{~m}^{3} \mathrm{~s}^{-1}$ occurred in July 1997:* first wave, ** second wave.
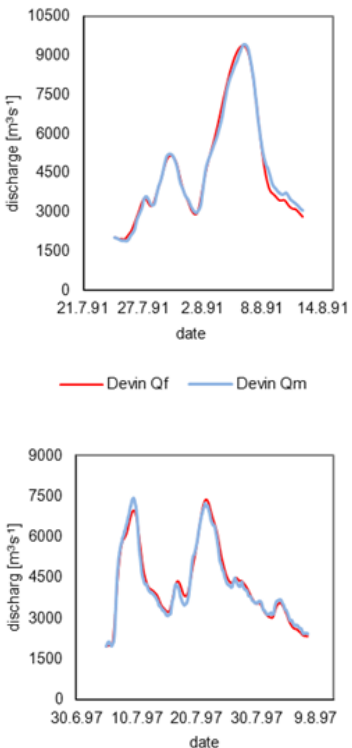

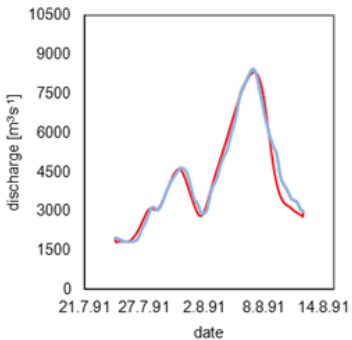

Medvedov Qm

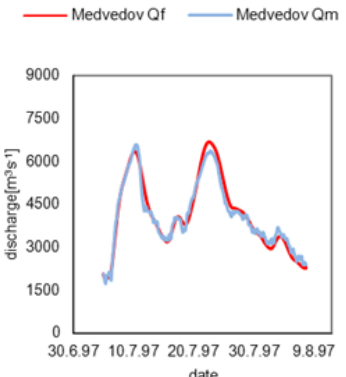

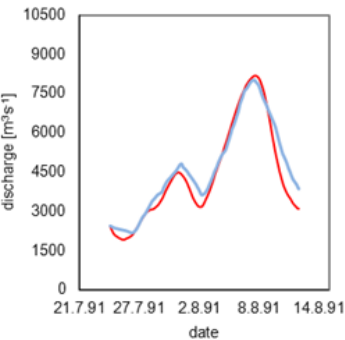

date

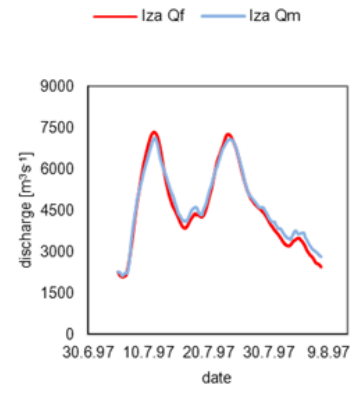

date

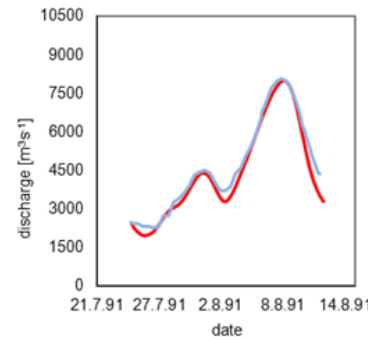

- Sturovo Qf - Sturovo Om

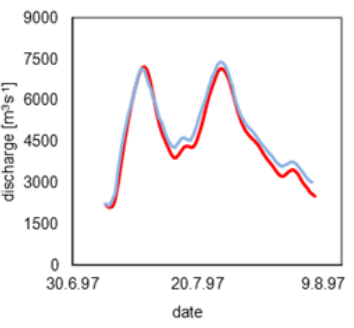

- Sturovo Qf - Sturovo Qm

Fig. 9. Validation of the NLN-Danube model at the Kienstock-Štúrovo reach (calibrated with August 2002 event). Validation with floods a) 1991 and b) $1997\left(Q_{m}\right.$ - measured discharges, $Q_{f}$ - simulated discharges). 
model on the Devín-Medved'ov reach seems quite difficult when related to the size of the peak discharge, but not to the time of its occurrence. The validation of the model calibrated with the floods of August 2002 as well as that of June 2013 showed comparable results at the Iža and Štúrovo gauging stations.

\section{Simulation of some historical flood wave transformations for the current Danube River regime conditions}

The June 2013 flood on the Danube River at Bratislava was the largest flood recorded and directly measured since the September flood in 1899 . In order to identify potentially dangerous flooding under the present Danube bed river conditions, the NLN-Danube model with the parameters of the June 2013 flood was used to simulate the historical flood wave transformations (the September 1899, July 1954, July 1965 and June 1975 floods). This station was chosen due to the availability of data. The flood in September 1899 was caused by a flood on the Inn River, a Danube tributary (Kresser, 1957). The peak of the flood reached a value of $11,200 \mathrm{~m}^{3} \mathrm{~s}^{-1}$ (972 $\mathrm{cm}$ stage) at the Stein Krems station and $10,500 \mathrm{~m}^{3} \mathrm{~s}^{-1}$ at the Vienna station. According to Angelini (1955), the peak water level of the wave at Bratislava reached a value of $970 \mathrm{~cm}\left(10,870 \mathrm{~m}^{3} \mathrm{~s}^{-1}\right)$. The largest flood on the Danube in the last century occurred in July 1954. The peak water level of the wave at Bratislava was observed with a value of $984 \mathrm{~cm}\left(10,400 \mathrm{~m}^{3} \mathrm{~s}^{-1}\right)$. The flood in 1965 was caused due to furrows of low pressure and heavy rainfall in the period of March-June 1965. Out of the series of six smaller waves, the highest culmination occurred in June 1965, when the culminated discharge reached a value of 9,170 $\mathrm{m}^{3} \mathrm{~s}^{-1}$ at Bratislava (the previous high flow rate of $6,000 \mathrm{~m}^{3} \mathrm{~s}^{-1}$ ).

The simulations showed that the peak discharges (over $8,000 \mathrm{~m}^{3} \mathrm{~s}^{-1}$ at Devín/Bratislava) were not changed significantly when compared to their historical counterparts; however, the simulated hydrographs exhibited an acceleration of the flood wave movement for discharges between 5,000 and $9,000 \mathrm{~m}^{3} \mathrm{~s}^{-1}$. The discharge of around $8,000 \mathrm{~m}^{3} \mathrm{~s}^{-1}$ would have arrived at Bratislava about 24 hours earlier. The simulations of the selected flood waves $(1899,1954,1965$ and 1975) by the NLNDanube model are presented in Figure $10 \mathrm{a}-\mathrm{c}$ for Devín/Bratislava.

\section{Catastrophic 1000-year flood simulation scenario}

The NLN-Danube model was used to simulate the transformation of a potentially catastrophic 1000-year flood event scenario. Based on archival records and publications concerning historical floods and flood marks (Figure 4b) along the Danube, a catastrophic flood occurred in August 1501 on the
Upper Danube River. Experience gained about the Danube summer floods indicate that the August, 1501 flood was probably caused by heavy precipitation, which must have had the same intensity in the Bavarian and Austrian parts of the Danube basin. The main sources of water in these areas are the Alpine tributaries of the Danube, and their culminations gradually met and contributed to a flood wave on the main river. The August 1501 flood is regarded by hydrologists as the largest flood for the last 600-1000 years in the Upper Danube. According to the historical flood marks, the peak discharge at Linz was estimated as being up to $12,000 \mathrm{~m}^{3} \mathrm{~s}^{-1}$ and was $14,000 \mathrm{~m}^{3} \mathrm{~s}^{-1}$ at Vienna. The water level of this flood with a value of $1,070 \mathrm{~cm}$ was reached in Stein-Krems (Kresser, 1957). Similar weather conditions caused the largest flood in the new millennium in June 2013. Blöschl et al. (2013) states that the city centre of Passau (at the confluence of the Danube, Inn and Ilz) experienced flood levels that were similar to the highest recorded flood in 1501. Therefore, the shape of the Danube flood hydrograph from 2013 was used as an input to the model for a simulation of the potentially catastrophic flood scenario. The discharges were multiplied so that the culmination matched the value of 14,000 $\mathrm{m}^{3} \mathrm{~s}^{-1}$ at the Kienstock water gauge station. Figure 11a presents the results of the simulated flood wave scenario for Devín/Bratislava. The simulation of the potentially catastrophic flood wave transformation from Kienstock to Stúrovo for the current Danube River regime conditions (calibration with the 2013 flood) is illustrated in Figure 11b, and the values of the simulated peak discharges are listed in Table 8 . The results of this simulated scenario showed that the travel time of the peak catastrophic flood wave could reach value of 50 hours from Kienstock to Devín/Bratislava, with a peak discharge a value of $13,475 \mathrm{~m}^{3} \mathrm{~s}^{-1}$ at Devín/Bratislava (this corresponds approximately to the water level a value of $1170 \mathrm{~cm}$ for recent river conditions on the Danube River at Bratislava). A similar simulation of the same catastrophic flood wave scenario based on the August 2002 flood (calibration with the August 2002 flood) was presented by Mitková (2005). The results of this simulation showed the peak discharge a value of $12,627 \mathrm{~m}^{3} \mathrm{~s}^{-1}$ (Table 8) at Devín/Bratislava. That corresponds to the water level value of $1,072 \mathrm{~cm}$ for the Danube River conditions in 2002 at Bratislava and the water level value of $1,080 \mathrm{~cm}$ for the Danube River conditions in 2013 with a travel time value of about 54 hours from Kienstock to Devín/Bratislava. The transformations of the same large flood waves on the Danube River from Kienstock to Stúrovo are illustrated in Figure 12a. The travel time of some extreme flood peaks is illustrated in Figure 12b. It shows that the travel time of the June 2013 flood at the Kienstock-Štúrovo river reach was similar to the travel time of the floods in August 2002 and 1899.

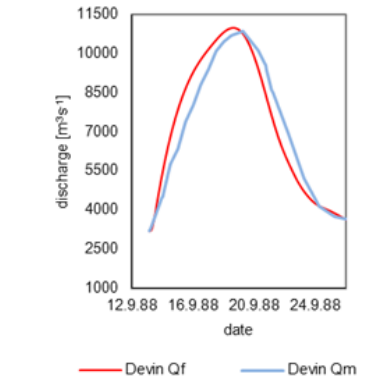

a

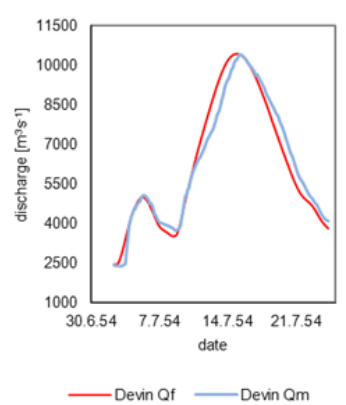

$\mathrm{b}$

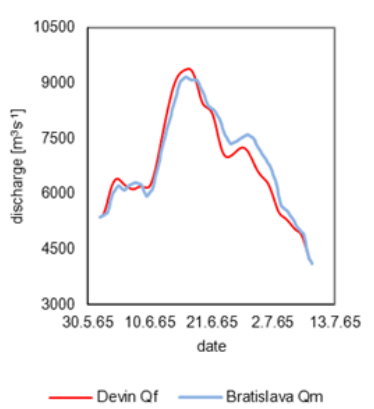

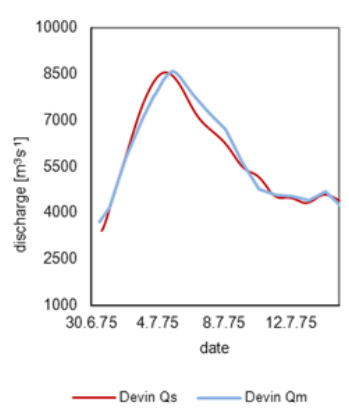

d

Fig. 10. Simulation of the flood waves that occurred in a) 1899, b) 1954, c) 1965 and d) 1975 on the Danube River in Bratislava by NLNDanube model calibrated with June 2013 event $\left(Q_{m}\right.$ - measured discharges, $Q_{f}$ - simulated discharges). 
Table 8. Comparison of the simulated scenario peaks based on floods in August 2002 and June 2013 for two individual calibrations from August 2002 and June 2013 (catastrophic flood scenario - $14000 \mathrm{~m}^{3} \mathrm{~s}^{-1}$ at Kienstock (flood in 1501).

\begin{tabular}{lccccc}
\hline flood peak & Kienstock & Devín/Bratislava & Medved'ov & Iža & Štúrovo \\
\hline peak $_{2002}\left[\mathrm{~m}^{3} \mathrm{~s}^{-1}\right]$ & 11,305 & 10,390 & 9,2400 & 8,940 & 9,103 \\
peak $_{1501}\left[\mathbf{m}^{3} \mathbf{s}^{-1}\right]^{*}$ & $\mathbf{1 4 , 0 0 0}$ & $\mathbf{1 2 , 6 2 7}$ & $\mathbf{1 1 , 1 7 4}$ & $\mathbf{1 0 , 7 2 2}$ & $\mathbf{1 0 , 6 9 0}$ \\
peak $_{1501}\left[\mathbf{m}^{3} \mathbf{s}^{-1}\right]^{* *}$ & 14,000 & 12,627 & $\mathbf{1 1 , 9 4 3}$ & 10,334 & 10,300 \\
peak $_{2013}\left[\mathrm{~m}^{3} \mathrm{~s}^{-1}\right]$ & 11,450 & 10,640 & 10,160 & 9,497 & 9,488 \\
peak $_{1501}\left[\mathbf{m}^{3} \mathbf{s}^{-1}\right]^{\circ}$ & 14,000 & 13,475 & $\mathbf{1 1 , 9 1 8}$ & 11,844 & 12,712 \\
peak $_{1501}\left[\mathbf{m}^{3} \mathbf{s}^{-1}\right]^{\circ 0}$ & $\mathbf{1 4 , 0 0 0}$ & $\mathbf{1 3 , 4 7 5}$ & $\mathbf{1 2 , 6 6 2}$ & $\mathbf{1 1 , 7 8 7}$ & $\mathbf{1 1 , 7 6 0}$ \\
\hline
\end{tabular}

Scenario based on flood in August 2002: *parameters of 2002 flood, **parameters of 2013 flood.

Scenario based on flood in 2013: ${ }^{\circ}$ parameters of 2002 flood, ${ }^{\circ}$ parameters of 2013 flood.

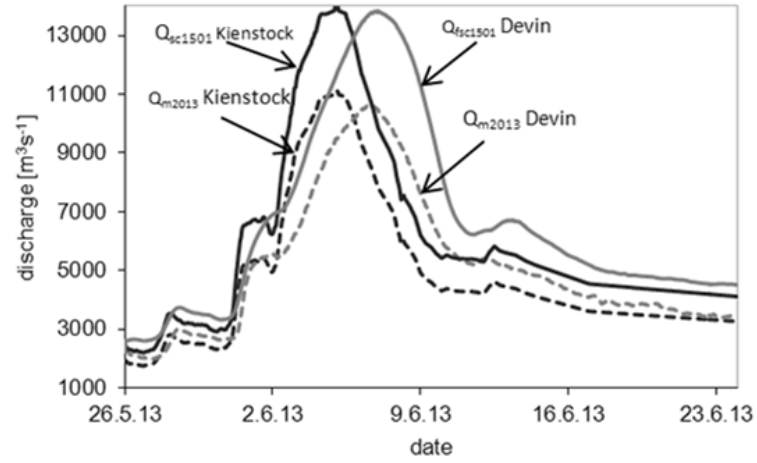

a

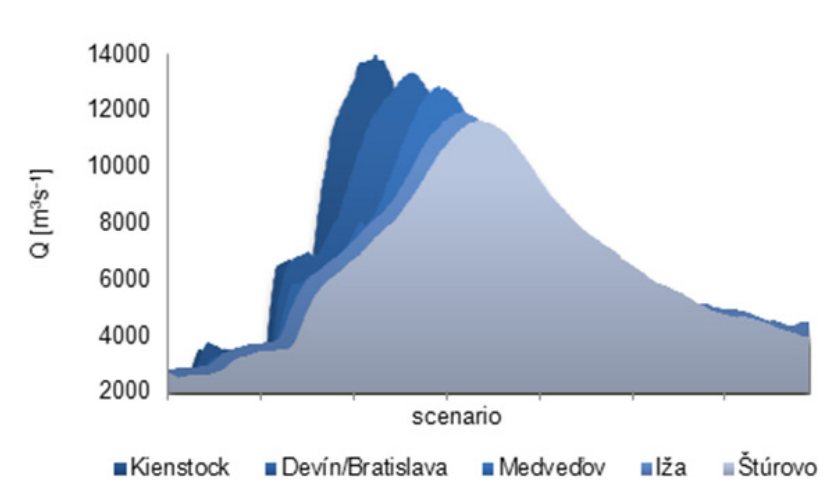

b

Fig. 11. Transformation of the simulated potentially catastrophic flood scenario on the Danube River by the NLN-Danube model calibrated with June 2013 event (peak discharge scenario at Kienstock 14,000 $\mathrm{m}^{3} \mathrm{~s}^{-1}$ (flood in 1501 based on flood in 2013) a) for Devín/Bratislava and b) from Kienstock to Štúrovo.
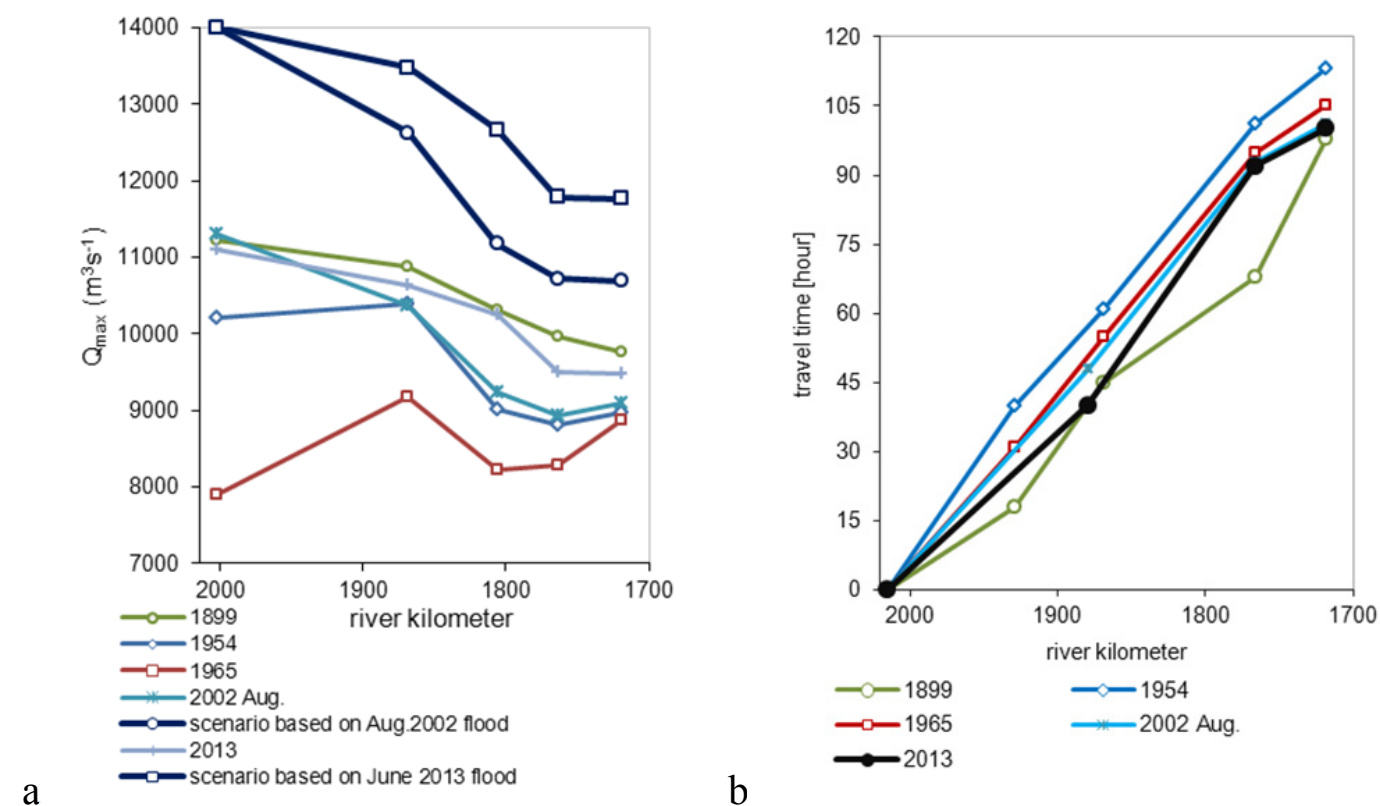

Fig. 12. Left panel a) transformation of the selected floods from Kienstock to Štúrovo on the Danube River. Right panel b) the travel time of the peak discharges of the selected floods on the Danube River from Kienstock to Štúrovo.

\section{CONCLUSIONS}

The flow regime conditions of the Danube River are continually changing. These changes result from natural processes (erosion, sedimentation, vegetation cover) or anthropogenic activities (modification of a river bank, construction of hydropower stations). This study presents a nonlinear reservoir cas- cade method to evaluate flood wave transformations on the Danube River. Based on this method, the NLN-Danube model was developed. The model simulates the transformation of Danube flood waves in four sections from Kienstock to Stúrovo under recent river bed conditions. The model was calibrated with the flood wave that occurred in August 2002, and validation was performed on some earlier floods that occurred on the 
Danube River. This calibrated and validated model was used for the real time forecasting of the discharges at Devín, Medved'ov, Iža and Štúrovo during the flood which occurred in late May and early June 2013 on the Danube River. Some calibration parameters $(N, B K, Q C$ and $E X)$ of the model were modified for recent river conditions, especially for Medved'ov. Consequently, the parameters for Iža and Štúrovo had to be modified. The results of the calibration for the June 2013 flood showed better agreement between the size of the measured and simulated discharges. The validation of the model with the June 2013 flood on some earlier floods from 1991-2010 showed overestimations of the peak discharges at the Medved'ov gauging station. The validation of the model with the June 2013 flood at the Iža and Štúrovo gauging stations showed comparable results. Svoboda et al. (2000) concluded that the results of such simulations could be influenced to quite a significant degree by external inflows (or outflows) and also by the operation of the Gabčíkovo power plant. Based on these results, the validation of the model with the June 2013 flood was compared with the validation of the model with the August 2002 flood on the same set of earlier floods. The comparison of the model validations with the August 2002 and June 2013 floods showed differences between the simulated peaks over of $500 \mathrm{~m}^{3} \mathrm{~s}^{-1}$. Improving the simulation at the Devín-Medved'ov section could be achieved by the classification of a new calibration parameter for the model in this section based on manipulation of the Gabčíkovo power plant. Such a parameter is included in the model as $N L$, but only as a value of $3 \%$ from the Devín discharges. We concluded that the calibration of the model at the Devín-Medved'ov section seems quite difficult when related to the size of the peak discharge, but not to the time of its occurrence. Despite the differences in the simulated peaks at Medved'ov, the model simulates the transformation of the flood wave rather well.

In the second part, the simulation of some historical floods $(1899,1954,1965$ and 1975) was performed. Finally, the transformation of the catastrophic flood scenarios of 2002 and 2013 for the Danube River was simulated by the NLN-Danube model. A historical flood event in the Upper Danube River in 1501 was used as a catastrophic flood scenario. The scenario of the transformation of a potentially catastrophic flood event for recent river regime conditions (corrected parameters) of the Danube River was simulated by the NLN-Danube model from Kienstock to Štúrovo. Next, a comparison of the transformation for the same catastrophic flood scenario, but based on the Danube flood of August 2002, was done. From the results of the comparison, we can assume that the travel times of high floods have not significantly changed during the last nine years at the Kienstock-Devín section. On the other hand, the peak water levels for recent river conditions are higher at the same discharges. The NLN-Danube model is a good tool for the simulation of historical floods as it does not need a large amount of input data. Compared to other modelling systems (such as GLOWA or LISFLOOD), it only requires discharges as input data. Therefore, the application of flood routing methods still remains a rational alternative under certain hydraulic conditions when the use of hydraulic models, due to their complexity and data intensity, may not be a feasible and economic solution.

Acknowledgements. This work was supported by the Vega project $2 / 0009 / 15$ and the results from the project implementation of the "Centre of excellence for integrated flood protection of land" (ITMS 26240120004) supported by the Research \& Development Operational Programme funded by the ERDF.

\section{REFERENCES}

Angelini, H., 1955. Danube flood in July 1954, Bratislava. Hydrological Study. HMI Department of Hydrology, Bratislava, Slovak Republic, 34 p. (In Slovak.)

Bardossy, A., Molnar, Z., 2004. Statistical and geostatistical investigations into the effects of the Gabcikovo hydropower plant on the groundwater resources of northwest Hungary. Hydrol. Sci. J., 49, 4, 611-623.

Blaškovičová, L., Danáčová, Z., Lovasová, L., Simor, V., Škoda, P., 2013. Evolution of selected hydrological characteristics of the Danube at Bratislava. Hydrological Final Report. Slovak Hydrometeorological Institute, Bratislava, pp. 1-15. (In Slovak.)

Blöschl, G., Nester, T., Komma, J., Parajka, J., Perdigão, R.A.P., 2013. The June 2013 flood in the Upper Danube basin, and comparisons with the 2002, 1954 and 1899 floods. Hydrol. Earth Syst. Sci., 17, 7, 9533-9573.

Brázdil, R., Kundzewicz, Z.W., 2006. Historical hydrology Editorial. Hydrol. Sci. J., 51, 5, 733-738.

Corbus, C., 2002. Contributions to approaching the floods propagation with the help of the theory of the systems. In: Proc. XXI Conference of the Danube Countries on Hydrological Forecasting (Bucharest, Romania). National Institute of Meteorology and Hydrology, Bucharest, ISBN 973-002759-5.

Čížová, M., 1992. Influence of hydrological forecast by anthropogenic activity. In: Proc. XVI Conference of the Danube Countries on Hydrological forecasting, Kelheim, Germany, pp. 301-305.

Danáčová, M., Szolgay, J., Výleta R., 2015. Estimation of the relationship between the travel time of flood peaks and peak discharge on the Poprad River by Multilinear flood routing. International Journal of New Technology and Research (IJNTR), 1, 6, 2015, 35-39. ISSN: 2454-4116

Goodrich, R.D., 1931. Rapid calculation of reservoir discharge. Civ. Eng., 1, 417-418.

Horváthová, B., 2003. Flood is not only the High Water. VEDA, Bratislava, 232 p. (In Slovak.)

Kalinin, G.P., Milyukov, P.I., 1957. On the computation of unsteady flow in open channels. Meteorol. Gidrol. Z., 10, $10-18$.

Kim, D.H., Georgakakos, A.P., 2014. Hydrologic routing using nonlinear cascaded reservoirs. Water Resour. Research., 50, 8, 7000-7019.

Kiss, A., 2011. Floods and long-term water-level changes in medieval Hungary. Doctoral dissertation. Central European University Budapest, Hungary, 323 p.

Kjeldsen, T.R., Macdonald, N., Lang, M., Mediero, L., Albuquerque, T., Bogdanowicz, E., Brázdil, R., Castellarin, A., David, V., Fleig, A., Gul, G.O., Kriauciuniene, J., Kohnova, S., Merz, B., Nicholson, O., Roald, L.A., Salinas, J.L., Sarauskiene, D., Sraj, M., Strupczewski, W., Szolgay, J., Toumazis, A., Vanneuville, W., Veijalainen, N., Wilson, D., 2014. Documentary evidence of past floods in Europe and their utility in flood frequency estimation. J. Hydrol., 517, 963-973. ISSN 0022-1694.

Kresser, W., 1957. The Flooding of the Danube. Springer Verlag, Vienna, Austria. (In German.)

Laurenson, M., 1964. A catchment storage model for runoff routing. J. Hydrol., 2, pp. 141-163.

Linsley, R.K., Kohler, M.A., Paulhus, J.L.H., 1949. Applied Hydrology. McGraw Hill, New York, pp. 502-530.

Malone, T.A., Cordery, I., 1989. An assessment of network models in flood forecasting. New directions of surface water 
modelling. In: Kavvas, M.L. (Ed.): Proceedings of Baltimore Symposium. IAHS 181. IAHS Press, Wallingford, pp. 115-124.

McCarthy, G.T., 1938. The unit hydrograph and flood routing. In: Proc. Conference of the North Atlantic Division of US Corporations of Engineers, New London, Conn.

Melo, M., Pišút, P., Melová, K., Viglaš, P., 2014. Historical flood marks from the 1775 Danube flood in Bratislava. Acta Hydrologica Slovaca, 15, 2, 308-319. (In Slovak.)

Mikhailova, M., Morozov, V., Cheroy N., 2012. Extreme hydrological events in the Danube River basin over the last decades. Water Resour., 39, 2, 161-179.

Mitková, V., 2005. Transformation of the flood waves of the Danube River in Kienstock - Sturovo reach. In: CD ROM Proc. Conf. Hydrological days 2005 - Hydrology for integrated management of the water resources and Conference of young specialists in hydrology, climatology and water managers. SHMI, STU, Bratislava, pp. 784-795, ISBN 8088907-53-5.

Mitková, V., Pekárová, P., 2003. The water levels forecast of the August 2002 flood of the Danube River at Bratislava station. Acta Hydrologica Slovaca, 4, 1, 176-182. (In Slovak.)

Mitková, V., Kubeš, R., Szolgay, J., Pekárová, P., 2004. Simulation of 1899 and 1954 Danube flood waves transformation in the river reach Kienstock - Bratislava in the present hydraulic conditions. Acta Hydrologica Slovaca, 5, 1, 52-62. (In Slovak.)

Mitková, V., Pekárová, P., Miklánek, P., Pekár, J., 2005. Analysis of flood propagation changes in the Kienstock - Bratislava reach of the Danube River. Hydrol. Sci. J., 50, 4, 655668.

Nash, J.E., 1957. The form of the instantaneous unit hydrograph. In: Proc. IAHS General Assembly, Toronto, Canada, pp. 3-14.

Nash, J.E., 1960. A unit hydrograph study with particular reference to British catchments, Proc. Inst. Civ. Eng., 17, 249282.

Opatovská, G., 2002. Influence of sedimentation on water level changes of Danube in Bratislava. Vodohosp. Sprav., 4, 1112. (In Slovak.)

Pekárová, P., Pekár, J., Miklánek, P., 2001. River model of nonlinear cascade NLN-Danube of Danube River between Ybbs and Nagymaros in EXCEL 97. Acta Hydrologica Slovaca, 2, 2, 241-246.

Pekárová, P., Szolgay, J., Mitková, V., Kubeš, R., 2004. Calibration of two hydrologic routing models of the Danube flood waves transformation between Kienstock - Bratislava river reach. Acta Hydrologica Slovaca, 5, 1, 24-33.

Pekárová, P., Miklánek, P., Melo, M., Halmová, D., Pekár, J., Bačová Mitková, V., 2014. Flood Marks along the Danube River between Passau and Bratislava. Veda, Bratislava, 102 p. ISBN 978-80-224-1408-1.
Perumal, M., Price, R.K., 2013. A fully mass conservative variable parameter McCarthy-Muskingum method: theory and verification. J. Hydrol., 502, 89-102. doi: 10.1016/j.jhydrol.2013.08.023.

Price, R.K., 1973. Flood routing methods for British rivers. Proc. Inst. Civ. Eng., 15, 913-930.

Price, R.K., 2009. Volume conservative non-linear flood routing. J. Hydraul. Eng. ASCE, 135, 10, 838-845.

Sahoo, B., 2013. Field application of the multilinear Muskingum discharge routing method. Water Resour. Manag., 27, 1193-1205. doi: 10.1007/s11269-012-0228-5.

Svoboda, A., 1969. Changes in flood regime along the river channel. Partial Report IH SAS, Bratislava. (In Slovak.)

Svoboda, A., 1970. Some practical aspects use the mathematical models in hydrology. J. Hydrol. Hydromech., 18, 3, 225-238.

Svoboda, A., Hajtášová, K., 1996. Comparison of short-term forecasting methods on the Danube used after completion of the Gabcikovo structure. In: Proc. XVIII Conf. of the Danube Countries. Technical University, Graz, Austria, pp. B133-B139.

Svoboda, A., Pekárová, P., Miklánek, P., 2000. Flood Hydrology of Danube between Devín and Nagymaros. SVH - IH SAS, Bratislava, $96 \mathrm{p}$.

Szilagyi, J., Pinter, N., Venczel, R., 2008. Application of a routing model for detecting channel flow changes with minimal data. J. Hydrol. Eng., 10.1061/(ASCE)10840699(2008)13:6(521), 521-526.

Szolgay, J., 2003. Multilinear discrete cascade model for river flow routing and real time forecasting in river reaches with variable wave speed. In: Montanari et al. (Eds.): Proceedings of the ESF LESC Exploratory Workshop on Hydrological Risk: recent advances in peak river flow modeling, prediction and real-time forecasting. Assessment of the impacts of land use and climate changes. University of Bologna, Bologna, Italy, $14 \mathrm{p}$.

Tang, X., Knight, D.W., Samuels, P.G., 2001. Wave speed discharge relationship from cross-section survey. Water and Maritime Eng., 148, 2, 81-96.

Tarpanelli, A, Barbetta, S., Brocca, L., Moramarco, T., 2013. River discharge estimation by using altimetry data and simplified flood routing modeling. Remote Sensing, 5, 9, 41454162. doi: 10.3390/rs5094145.

Todini, E., 2007. A mass conservative and water storage consistent variable parameter Muskingum-Cunge approach. Hydrol. Earth Syst. Sci., 11, 1645-1659.

Wong, T.H.F., Laurenson, E.M., 1984. A model of flood wave speed - discharge characteristics of rivers. Water Resources Res., 20, 1883-1890.

Received 25 January 2016 Accepted 14 September 2016 